\title{
Direitos Humanos: VIOLÊNCIA E POBREZA NA AmÉrica Latina Contemporânea
}

\section{Human Rights: violence and poverty in Contemporary Latin America}

\author{
Aline Silveira de Assis* \\ FREIRE, Silene de Moraes (Org.). Direitos Humanos: violência e pobreza na \\ América Latina Contemporânea. Rio de Janeiro: Letra e Imagem, 2007.
}

O livro que ora chega ao público reflete a preocupação da Extensão com os direitos humanos e reúne artigos que foram apresentados no âmbito do "I Seminário Internacional de Direitos Humanos, Violência e Pobreza: a situação de crianças e adolescentes na América Latina Contemporânea hoje", realizado pelo Programa de Estudos de América Latina e Caribe (PROEALC), do Centro de Ciências Sociais, da Universidade do Estado do Rio de Janeiro (CCS/ UERJ), lócus da extensão nas Ciências Sociais. O tema não poderia ser mais oportuno. É uma brilhante iniciativa que mostra a preocupação com os Direitos Humanos em um contexto tão adverso de deterioração da esfera pública e desresponsabilização do Estado na garantia dos direitos humanos. No contexto da globalização hegemonizada pelo capital financeiro, sociedades periféricas, como a brasileira, com uma herança histórica de violações de direitos humanos, arbitrariedades e injustiça social, aprofundam o contexto de desigualdade e da cidadania diferenciada, vale dizer, esta agora restrita ao âmbito do consumo. Os processos de democratização formal destas sociedades não são suficientes para mudar o quadro de vio- lência que historicamente faz parte do cenário sociocultural, e que atinge principalmente os segmentos subalternos, categorizados como "populações de risco", propensos a serem banalizados em uma sociedade cada vez mais individualista, desigual e excludente. Como conseqüência do desmantelamento do Estado, há uma ausência de políticas públicas voltadas para a infância e juventude brasileiras, e sim um grande investimento para combater a violência, que resulta num processo de disciplinamento e extermínio desta juventude, revelando um verdadeiro "infanticídio". Na verdade, as políticas desenvolvidas neste campo refletem uma combinação desta repressão com o assistencialismo presente em certos programas e projetos destinados a esta população. Não é casual afirmar que o discurso contra o crime e da repressão como instrumento para seu combate vem sendo muitas vezes estimulado, inclusive nos meios de comunicação $e$, conseqüentemente, naturalizado pela sociedade brasileira nos últimos anos. Assim sendo, destaca-se uma preocupação especial com o destino de crianças e adolescentes na América Latina, as quais vem sendo as principais vítimas desse processo de crescente

\footnotetext{
Mestre em Serviço Social pelo Programa de Pós-Graduação da Faculdade de Serviço Social da Universidade do Estado do Rio de Janeiro (PPG/FSS/UERJ) e Bolsista de Apoio Técnico-Científico do Programa de Estudos de América Latina e Caribe (PROEALC/CCS/ UERJ). Endereço: Rua Antônio Rego, 1389 - Olaria / Rio de Janeiro - RJ. CEP 21073-311. Telefone: (21) 2573-1389 / 9311-2298. E-mail: aline-silveira@ig.com.br.
} 
criminalização da pobreza. Mas o pessimismo que deveria orientar tais constatações não foi maior que o otimismo que levou o PROEALC a realizar este seminário e a produzir esta publicação, cuja relevância se sustenta na contribuição oferecida a todos os que pensam e defendem os direitos humanos em uma região tão desigual como a América Latina.

Neste sentido, a coletânea reúne especialistas de diversas áreas que trouxeram dados objetivos e abordagens esclarecedoras, muitas das quais francamente polêmicas. O leitor encontrará nestas páginas reflexões referentes às questões da infância, adolescência, juventude, violência, pobreza e direitos humanos, mostrando como os impactos e desafios das persistentes desigualdades na América Latina e as diferentes formas de enfrentamento ameaçam cada vez mais as gerações futuras da região, revelando, inclusive, a relação que a mídia tem no obscurecimento da violência contra crianças e adolescentes e na naturalização da criminalização. Entretanto, o debate travado no livro propõe, dentro de uma perspectiva transformadora, políticas a partir das quais é possível garantir os direitos da infância e da juventude. Sendo o PROEALC um Programa de Extensão, esta iniciativa é mais que um trabalho acadêmico, ela revela o compromisso do Programa com o resgate da universidade pública, cujas atividades devem ser destinadas à produção de conhecimento, o qual por sua vez deve ser socializado à população, atendendo aos interesses das classes subalternas em direção à emancipação humana. E isto vai na contramão das perspectivas "mercantilizadoras" presentes na universidade.
Certamente, pela sua riqueza e rigor teórico, esta produção será referência para a efetivação dos direitos humanos na sociedade contemporânea, não só no Brasil, mas em toda a América Latina. O livro, composto por 18 artigos, passa a ser leitura obrigatória aos que se preocupam com a efetivação dos direitos humanos no século XXI. Ampliando o leque de temas relacionados a essa questão, a publicação traz ao público questões como: a política de cotas nas universidades públicas brasileiras, que a princípio o leitor não associa à questão dos direitos humanos, mas cuja compreensão é de suma importância na luta pela afirmação dos mesmos; o significado da esfera pública para a democracia; políticas públicas e efetivação dos direitos humanos; a política de segurança pública e o sistema penitenciário; a invisibilidade do abandono de crianças e adolescentes no Brasil; dentre outros, evidenciando a profunda relação das mesmas com os direitos humanos.

Em resumo, a coletânea em foco demonstra o vigor dos Programas de Extensão das Universidades Públicas latino-americanas no processo de resistência contra a banalização e o aviltamento dos direitos humanos na atualidade. Resgatando, desse modo, o compromisso da Extensão com a realidade em que se insere. Ou como evidencia FREIRE na apresentação: "a relevância dessa publicação não se resume à reconhecida qualificação de seus autores. Acima de tudo, ela se sustenta na contribuição que oferece a todos aqueles que se dispõem a pensar a defesa dos direitos humanos opondo-se aos rumos de sua negação, impostos pela agenda neoliberal" (p. 9).

Texto recebido em 21 fev. 2008 Texto aprovado em 26 mar. 2008 